\title{
SUMMARY \\ Repressions of the Soviet State against the Ukrainian Greek Catholic Church in 1939-1989 in contemporary domestic historiographical discourse
}

The main contributions of modern domestic historiography to the study of the Communist totalitarian regime's repressive policy against the Ukrainian Greek Catholic Church in the years 1939-1989 are analyzed. Investigation is based on fundamental principles of historical research such as scientific objectivity and historicism. The source base includes monographs, dissertations, scientific articles, materials of the conferences and the scientific and documentary book series "Rehabilitated by History". The focus is on basic opinions and conclusions of scholars concerning the causes, forms, types and consequences of punitive measures of the Communist-Soviet regime against clergy and believers of the Ukrainian Greek Catholic Church in this period and an outline on the prospects for further studies of the topic. The scholarly contribution of this research is that it created an integral picture of modern domestic historiography to the study of the repressive measures of the Soviet state against the Ukrainian Greek Catholic Church in this period.

It is established that the domestic researchers, based on extensive sources, have analyzed the causes, forms, types and consequences of the repressions, and have considered the specifics of the repressive measures against clergy and believers of the Ukrainian Greek Catholic Church in regions of Western Ukraine. Some scientific works of domestic researchers are dedicated to victims of the Communist totalitarian regime's repressive policy against the Ukrainian Greek Catholic Church. The research of Ukrainian historians, who specialize on these issue, show that repressions against the Ukrainian Greek Catholic Church in the years 1939-1953 were inspired and carried out under the close control of the top leadership of the country. They were directed to the national liberation movement of Western Ukraine and have become an integral part of Sovietization and have contributed to the establishment of the Communist-Soviet regime in Western Ukraine. The Communist-Soviet regime continued repression against the leaders and members of the Catacomb Church in the years 1954-1989.

Keywords: the Ukrainian Greek Catholic Church (UGCCh), the Communist-Soviet regime, state security agencies (The People's Committee for Internal Affairs-Committee for State Security), punitive measures, prosecution, deportation

DOI 10.33294/2523-4234-2019-29-1-167-177

Олена Луців

\section{Пізньопротестантські спільноти в Україні (XIX - початок XXI ст.)}

Досліджено історію зародження та функціонування пізньопротестантських спільнот на теренах України впродовж XIX - початку XXI ст. Також, приділяється увага сучасним тенденціям розвитку пізньопротестантських спільнот, зовнішнім та внутрішнім напрямам діяльності та організації праці з молоддю. Виявлено, що український протестантизм XXI ст. перебуває на ідейному та ціннісному роздоріжжі, де ще цілковито не відкинуті старі, проте й не прийняті нові бачення та стратегії його розвитку.

Ключові слова: протестантизм в Україні, ранній протестантизм, пізній протестантизм, баптизм, п'ятидесятництво, молодь у протестантських Церквах 
У сучасній українській науці перші дослідження історії протестантизму 3'являються наприкінці 90-х рp. XIX ст. Якщо поява та функціонування католицизму та православ'я на теренах України є об'єктом багатьох вітчизняних досліджень, то протестантизм привертає меншу увагу дослідників та відповідно у працях висвітлюється рідше. Насамперед, це пов'язано з тим, що протестантизм у нас з'явився значно пізніше, аніж інші течії християнства. Проте, починаючи з XIX ст. він дедалі впевненіше посідає своє місце на релігійній мапі нашої держави. Особливо протестантизм набув свого поширення після завершення епохи тривалої радянської атеїстичної діяльності, коли впродовж десятиліть він був у вигнанні. Саме з постанням незалежності України протестантизм спромігся не лише зберегти свої осередки але й поширити унікальний християнський світогляд. Зросла і кількість досліджень цієї релігійної течії в Україні.

Сьогодні вивчення протестантизму представлене у доробку багатьох вітчизняних дослідників: А. Колодного [1; 2], П. Яроцького [1; 2; 3], В. Любащенко [4; 5], М. Мокієнка [6], М. Черенкова [7; 8; 9], С. Буги [10; 11], В. Докаша [12; 13; 14] та інших. Зокрема, однією із найбільш грунтовних праць з історії раннього та пізнього протестантизму від часу його появи в Україні і до нині, це колективне дослідження науковців Інституту філософії НАН України (А. Колодного, П. Яроцького, В. Креміня та О. Сагана). Це дослідження складає п'ятий та шостий томи багатотомника “ІІторія релігій в Україні”. У праці належну увагу приділено діяльності протестантів у повоєнні роки, у радянський період та у незалежній Україні [22].

Історія раннього та пізнього протестантизму в Україні також широко представлена у працях В. Любащенко. Дослідниця не лише комплексно вивчає передумови та явища, які вплинули на формування протестантських спільнот, але й аналізує вплив світових реформаційних процесів на українське суспільство. Також, В. Любащенко робить висновки про причини, умови та специфіку появи протестантських спільнот в середовищі українців [4; 5].

М. Мокієнко спрямовує свій дослідницький фокус на становлення пізньопротестантських течій в Україні впродовж 1991-2004 рр., відображаючи специфіку євангелізаційно-місіонерської діяльності пізнього протестантизму, становлення та розбудову пізньопротестантських навчальних закладів та участь протестантів у політичному житті України - президентських виборах 2004 р. та Помаранчевій революції. М. Мокієнко відзначає, що сучасним пізньопротестантським громадам притаманна активність, відкритість до зовнішнього світу та бажання брати участь у державних суспільно-політичних подіях [6].

Дослідженням пізньопротестантських течій в Україні займається також М. Черенков, котрий приділяє увагу проблемам секуляризації, соціально-богословській ідентичності євангельського протестантизму, стосункам протестантизму з державою та іншими конфесіями тощо. Також, цінним здобутком М. Черенкова $є$ аналіз сучасних тенденцій та викликів у протестантизмі. Дослідник зазначає, що сьогодні 
протестантизм перебуває на стадії переходу від ізоляціонізму та сепаратизму до соціалізації та відкритості суспільству [7; 8; 9].

Роботи С. Буги розкривають історію виникнення та діяльності пізньопротестантських течій в Україні. С. Буга зазначає, протестантизм сьогодні - це активна й динамічна громада людей, що дедалі більше бере участь у соціокультурних перетвореннях в українському суспільстві $[10 ; 11]$.

Зацікавлення В. Докаша зосереджуються на формах соціальної адаптації та входженні вірян у програми та напрями служіння протестантських Церков. Крім того, об’ єктом дослідження В. Докаша є протестантська есхатологія та їі основні елементи (рай, пекло, смерть, воскресіння, прихід Христа та інше). Ще однією темою дослідника став модернізм та його вплив на розвиток протестантизму в Україні. В. Докаш зазначає, що найбільше вплив модернізму простежується у соціальній сфері, де розширилася мережа позацерковної діяльності вірян, з’явилися програми та проекти, спрямовані виховувати молодь у релігійному дусі, удосконалилися робота релігійних організацій та спільнот. Також, розширилася та вийшла на новий рівень харитативна діяльність протестантів [12; 13; 14$]$.

Для доповнення та розширення існуючих поглядів на історію зародження та діяльності пізньопротестантських спільнот в Україні впродовж XIX - початку XXI ст. на теренах України було проведено авторське польове дослідження методом експертних інтерв'ю, що тривало із листопада 2017 по 1 березня 2018 рр. Запитальник до інтерв’ю включав такі теми: розвиток та функціонування молодіжних середовищ при Церквах; діяльність, структура та комунікація у молодіжних середовищах; особливості формування молодих християн, церковна та позацерковна діяльність молодих людей. Таким чином, мета статті - висвітлити історію появи та діяльності пізньопротестантських спільнот в Україні з призми поєднання авторського дослідження з історичними джерелами у сучасній науковій літературі.

Експертами були обрані особи, які є членами протестантського середовища, а саме пастори, релігієзнавці, історики: Ярослав Емха - пастор Львівської церкви християн віри євангельської “Віфанія”; Іван Білик - пастор Львівської церкви християн віри євангельської “Життя”, керівник молодіжного відділу Церкви християн віри євангельської у Львівській області; Ярослав Назаркевич - пастор Львівської центральної церкви євангельських християн-баптистів “Дім Свангелія”; Володимир Салайдяк ректор Львівської богословської семінарії, викладач, диякон; Богдан Луць - пастор Центральної церкви євангельських християн-баптистів “Дім Свангелія"; Михайло Хром’як - релігієзнавець, історик, декан заочного відділення Львівської богословської семінарії; Володимир Гірняк - пастор Львівської церкви християн віри євангельської "Голгофа"; Михайло Мокієнко - історик, релігієзнавець, науковий співробітник Ресурсно-дослідницького центру Свро-Азіатської акредитаційної асоціації.

Протестантизм (від лат. “protestans” - заперечувати щось) сформувався у XVI ст. внаслідок Реформації християнського світогляду у Свропі [див.: 15, с. 290]. Ініціатором Реформації був німецький священик Мартін Лютер, котрий виступав 
проти католицького віровчення. Насамперед, Лютер вважав, що найважливішою у будь-якому релігійному вченні повинна бути віра та особисті стосунки людини з Богом. Відповідно ікони та статуї заперечуються як діалогічні форми стосунків людини з надприроднім. Крім того, Лютер наголошував, що слід визнавати канонічність лише Святого Письма, як завершеного Божого відкриття, якого $\epsilon$ достатньо для повноцінного життя людини, тоді як у Католицькій церкві визнається і Священне писання, і Священне передання. Також, Лютер вбачав необхідним існування лише двох Святих Таїнств: хрещення та євхаристії, на відміну від католицизму, де визнаються сім Святих таїнств [4; 1, с. 20-95]. Згодом усі ці погляди переросли у нове релігійне вчення - лютеранство.

Під впливом ідей Лютера, наприкінці XV - на початку XVI ст., утвердилися ще кілька ранньопротестантських напрямів. Один із них це кальвінізм (за ім'ям французького проповідника Жана Кальвіна). Його основна відмінність від лютеранства полягає в розумінні спасіння людини. Ще до народження доля людини наперед визначена. Відповідно, $є$ ті люди котрим Бог подарує спасіння, а $є$ ті кому - ні [15, c. I-XI; 16, с. 480-482]. Інший напрям у протестантизмі - цвінгліанство (за ім'ям швейцарського реформатора Ульріха Цвінглі) відрізняється від лютеранства більшим радикалізмом. Цвінглі відкидав необхідність будь-яких церковних атрибутів, до прикладу ікон, вівтаря, дзвону, хрестів тощо [16, с. 1168-1169]. Таїнства євхаристії та хрещення розглядалися більше як релігійні символи, які уособлюють пам'ять та пошану до Ісуса Христа та входження людини до Церкви. Не отримавши значної підтримки цвінгаліанство наприкінці XVI ст. злилося з кальвінізмом. Ще одним напрямом протестантизму стало англіканство - поєднання поглядів католицизму та протестантизму, яке утворилося в Англії під впливом Реформації. Англіканство, як і католицизм, не відкидає ідею спасіння людини за допомогою Церкви. Проте, поділяє погляди лютеранства та кальвінізму і визнає лише два таїнства, відкидає культ святих та необхідність ікон [17, с. 26-28, 303-304]. 3 плином часу та нових викликів у суспільстві наприкінці XIX - початку XX ст. у протестантизмі відбулися трансформації, що привели до появи цілковито нових пізньопротестантських напрямів: п'ятидесятницва (від свята П'ятидесятниці-зіслання Святого Духа на апостолів у п'ятдесятий день після Воскресіння Ісуса Христа [17]), баптизму (грець. "baptizo" - хрестити у воді [15, с. 53]), адвентизму (лат. "adventus" - пришестя [14, с. 16]).

На теренах України перші ранньопротестантські спільноти з'явилися у першій половині XVI ст. Серед них були лютерани на Галичині й Закарпатті, а також кальвіністи на Волині, Поділлі та Київщині. Ці спільноти об'єднували невелику кількість вірних та не змогли надовго вкоренитися у суспільстві [1, с. 23-57]. Проте, вони дали поштовх для подальшого розвитку протестантизму в середовищі українців та пробудили новий етап духовних шукань людей. Більшої прихильності й симпатії серед українців отримали пізньопротестантські течії. Саме молоді люди, які емігрували за кордон заради навчання чи працевлаштування захоплювалися та 
наверталися у протестантизм. Згодом, ті що повернулися на батьківщину, проповідуючи, навертали своїх родичів та друзів. Таким чином ранньопротестантські погляди були витіснені пізньопротестантськими, серед яких до сьогодні найбільшу кількість прихильників налічують громади євангельських християн-баптистів та християн віри євангельської (п'ятидесятників) [19]. Серед основних причин, які пробуджували цікавість українців до протестантизму була насамперед можливість по-новому інтерпретувати текст Святого Письма та особисту комунікацію з Ісусом Христом. Також, яскравою була відмінність у релігійних традиціях, практиках та формах служіння. Слід зауважити, що спочатку на теренах України протестантизм налічував поодиноких прихильників, проте згодом утворилися цілі протестантські осередки та громади, які активно розповсюджували нове релігійне вчення серед населення. Отже, зупинимося на історії та специфіці розвитку саме цих двох найбільш чисельних пізньопротестантських течій в Україні.

Історія появи баптизму датується серединою XIX ст., коли на півдні сучасної України у с. Основи (Херсонська губернія Російської імперії) вперше виникли спільноти штундистів. Варто деталізувати, що штундизм як протестантська течія передбачав зібрання на яких поширювався та обговорювався зміст Свангелія, які тривали близько години. Відповідно до цього утворилися назва штундизм, адже “штудне" у перекладі з німецької означає година. Першим хто долучився до цієї течії був Федір Онищенко. Ще одна видатна постать євангельської громади Іван Рябошапка. Він не тільки поширював ідеї цього напряму, але й сам активно здійснював низку релігійних практик, серед яких хрещення, причастя, відспівування [1, с. 305-307]. У 1867 р. відбулася визначальна подія в історії баптизму. Прихильники штундизму вперше здійснили обряд водного хрещення згідно 3 баптистською традицією. Після цього обряд хрещення набув значного поширення та здійснювався не поодиноко як було до цього [5; 20, с. 93-94].

Історія виникнення п'ятидесятництва в Україні пов'язана з ім'ям Івана Воронаєва, котрий емігрувавши до США захопився баптизмом. Згодом він поступив на навчання до баптистської богословської семінарії в м. Берклі (штат Каліфорнія). Проте, у 1919 р. долучився до п’ятидесятництва, і став його проповідником. У 1920 р. Воронаєв повернувся в Україну, а саме до Одеси. Слід зазначити, що він отримав підтримку ще від кількох осіб, які разом з ним проповідували в Одесі [2, с. 42-44]. Саме завдяки проповідям та залученням до громади людей п'ятидесятництво активно поширилося й на інші території, що охоплюють нинішні Київську, Полтавську, Дніпропетровську, Чернігівську області України. У зв' язку зі збільшенням чисельності громади християн віри євангельської було вирішено провести перший обласний з'їд, який відбувся у 1924 р. в м. Кременець. Через два роки, у 1926 р. в Одесі відбувся перший Всеукраїнський з'їзд християн віри євангельської [2, с. 45-48; 18$]$.

Динамічному розвитку баптизму у Західній Україні наприкінці XIX - початку XX ст. сприяли місійні працівники: Іван Підгорецький, Василь Перетятко, Лев 
Жабко-Потапович та інші. Водночас п'ятидесятнитцво розвивалась завдяки зусиллям Трохима Нагорного, Йосифа Антонюка та Порфирія Ільчука. Зусиллями Григорія Федишина та Івана Петраша у 20-х рр. XX ст. на території Львівської області вперше з'явилися п'ятидесятницькі та баптистські громади [2, с. 69-70; 21].

Кінець 20-х pp. ХХ ст. для усіх протестантських громад у підрадянській Україні склався трагічно, адже радянська влада розпочала репресії проти членів громад. Зокрема, значна частина лідерів були заарештовані та відіслані у концтабори, інших розстріляли. Була заборонена релігійна діяльність не тільки в Домах молитви, але й у приватних будинках. Займатися харитативною та просвітницькою роботою також було суворо заборонено.

Особливий акцент радянська влада робила на обмеженні праці з молоддю. Фактично була під забороною будь-яка діяльність, спрямована на людей молодших 18 років. Така ситуація тривала аж до початку Другої світової війни. У наступній декаді XX ст. протестантам займатися релігійною діяльністю було небезпечно для життя. Проте, все ж таки існували осередки де таємно проводилися зібрання, хоча їхня кількість була не значною. Після завершення війни постало питанням про відновлення діяльності Союзу п'ятидесятників у зареєстрованих громадах. Проте, радянська влада дотримувалася чіткої позиції, що Союз може існувати лише один: або це Союз п'ятидесятників або баптистів. Для того, щоб зберегти свої громади та продовжувати діяльність було прийнято рішення про укладення спільного Союзу. Ця подія відбулася 25 серпня 1945 р. та отримала назву Серпнева угода, яка тривала 44 роки [2, с. 57-60; 23, с. 386-388].

На початку 50-х рр. XX ст. становище протестантів дещо покращилося, адже було звільнено чимало засуджених за проповідницьку діяльність. На перший погляд видається, що влада врешті-решт попустила короткий повідок на якому тримала у своїх руках протестантів, проте у 1957 р. розпочався новий етап репресій. Не лише питання про реєстрації громад, але й про їхнє існування було категорично відкинуте та закрите на довгих 12 років [2, с. 164-167; 18]. Цей період можна описати як намагання віднайти бодай якийсь шлях власного розвитку, волевиявлення та свободи.

На початку 60-х pp. ХX ст. у середовищі протестантів відбувся розкол. Його основна причина - ухвалення на засіданні Всесоюзної ради євангельских християн-баптистів у 1959 р. нового Положення про Союз євангельских християнбаптистів та Інструктивного листа. Рада вирішилися піти на поступки радянській владі заради збереження громад та спільнот. Ці два документи регламентували діяльність баптистів, обмежуючи та змінюючи визначальні для них традиції та практики. До прикладу, будь-якого роду співи, хори, виступи, промови не повинні існувати у щоденних богослужіннях. Ще одна болюча постанова декларувала, що проводити богослужіння можна лише в приміщенні церкви, що виходило за рамки усталеної традиції баптистів проводити богослужіння в Молитовних домах. Відповідно частина баптистської громади погодилися з цими рішенням, 
на противагу іншій яка не виявила бажання змиритися 3 такими утисками та від’єдналася від Союзу. Протягом наступних років відбулися спроби віднайти порозуміння та шляхи до примирення. Лише у 1970 р. значна частина баптистів знову доєдналася до Союзу [20, с. 178-198].

Наприкінці 80 - початку 90-х pp. ХХ ст., після розпаду Радянського Союзу усі протестантські спільноти вперше мали змогу проповідувати слово Ісуса Христа за межами Дому молитви, без страху потрапити під кримінальне переслідування та арешт. Адже, до цього зібрання здебільшого відбувалося у приватних будинках віруючих, де пастори на свій ризик намагалися проводити навчання Біблії. Цей час варто охарактеризувати як період динамічного зростання пізньопротестантських спільнот. Фактором, який притягував людей різного віку були виразні форми служіння зі співами й читаннями віршів.

Вороже та безжалісне ставлення радянської влади до віруючих, спонукали людей до ще більшого об'єднання та комунікації, адже спільноти стали не лише місцем, де людина мала змогу поділитися з однодумцями своїми душевними переживаннями, але й місцем де без страху і ризику кожний міг відкрито позиціонувати себе як релігійна особистість.

Із проголошенням незалежності України відбулося духовне-моральне піднесення серед усіх протестантських спільнот. Громади вперше вийшли з підпілля та відчули свободу в усіх сферах діяльності. Одним із таких прикладів волевиявлення було проведення євангелізацій - донесення сутності Свангелія до людей під відкритим небом. Саме 90-ті рр. ХХ ст. були вершиною євангелізаційних служінь, адже запит був не лише серед людей старшого покоління, а й серед молоді. Цей період слід охарактеризувати як “релігійний бум”, який охопив ціле українське суспільство [23].

Ще одне важливе зрушення у протестантизмі, після проголошення Незалежності пов’язане з появою духовних навчальних закладів та християнської літератури. За часів Радянського Союзу протестанти не мали змоги здобути вищу освіту. Навіть отримати середню спеціальну освіту було великим досягненням. Адже здобуття вищої освіти неодмінно було пов'язане із вступом до комсомолу, вимогою якого було пропагування атеїстичного способу життя. Протестантська молодь відмовлялася вступати до комсомолу. Це означало втрату будь-яких шансів на здобуття освіти. Сдиним способом якимось чином поглибити свої знання про Бога, було відвідування біблійних курсів у Москві, адже в Україні не було жодної протестантської освітньої установи. Ще однією можливістю було пізнати Боже слово самостійно. Проте, у Радянському Союзі існувала лише Біблія російською мовою православного видання, натомість сьогодні протестанти мають змогу не лише ознайомитись але й у вільному доступі придбати Біблію українською мовою [24].

Слід зауважити, що сьогодні функціонує Українська баптистська теологічна семінарія у Львові, Києві та Одесі, а також Київський християнський університет і Таврійський християнський інститут. До 2014 р. діяв Донецький християнський університет 
[1, с. 420-423]. У Західній Україні провідним духовним вищим навчальним закладом $\epsilon$ Львівський біблійний інститут (з 2004 р. Львівська богословська семінарія). Станом на двотисячні роки Львівська богословська семінарія налічує близько 15 філіалів в межах України [25]. Отже, сьогодні протестанти не обмежені у своєму виборі, адже за своїм покликом та бажанням мають змогу обрати як духовний навчальний заклад так і найрізноманітніші біблійні курси та навчальні програми.

На початку XXI ст. діяльність пізньопротестантських спільнот урізноманітнилася та розширилася. Якщо у 90-х рр. XX ст. праця не виходила за рамки церковного середовища та була націлена на вирішення внутрішніх проблем громади, то у двотисячних роках відбулося збільшення зовнішньозорієнтованої форми діяльності. Протестанти активно допомагають реабілітаційним центрам, лікарням, сиротинцям тощо. Серед соціальних напрямів, до яких залучені протестанти варто виділити нещодавно створену всеукраїнську акцію євангельських протестантських Церков “Чисте серце - чисте місто", яка була приурочена святкуванню 500-річчя Реформації. Основна мета - це прибирання та облаштування територій міста, тим самим покращення не лише свого простору, але й простору інших. Крім цього з'явилися різноманітні форми проведення дозвілля, як у межах Церкви так і поза нею. Сьогодні при протестантських громадах функціонують спортивні, музичні, поетичні, соціальні гуртки для усіх охочих [26].

Внутрішньо-зорієнтована форма діяльності також удосконалилася та набула ширших форм. До прикладу, усталеною $є$ практика проведення всеукраїнських та обласних з'їздів протестантів. Один із найважливіших заходів у цій сфері $\epsilon$ щорічний всеукраїнський з'їзд - “Малинфест”. Він відбувається в м. Малин (Житомирська область) та налічує від 5 до 8 тисяч людей. Саме цей фестиваль $\epsilon$ місцем зародження нових ідей та поглядів у протестантизмі, адже учасники фестивалю - це найбільш активна та ініціативна молодь з усіх областей України [27]. Слід відзначити, що особливістю таких фестивалів є їхній чіткий розклад та структура, націлена як на об’єднання та спілкування у громадах, так і на поглиблення вивчення Божого слова.

Ще одна характеристика, яка вирізняє сучасний протестантизм у двотисячних роках - це проведення та координування діяльності, що має на меті мотивувати молодь доєднатися до церковного середовища. Одним із таких прикладів є утворення домашніх груп, до яких запрошуються молоді люди, котрі не є частиною протестантського середовища (друзі, однокласники, одногрупники, знайомі тощо). Зібрання у таких групах, як можна зауважити з назви, проходять у домах віруючих. Вони відбуваються щотижня та налічують від 5 до 18 осіб. Особливістю цих груп $\epsilon$ відсутність будь-якого контролю щодо формату проведення або ж структури зібрань. Такі домашні групи відбуваються у формах бесіди чи чаювання [26].

Наступний приклад - створення “Асоціації євангельских студентів” у 2016 р. за ініціативи молодіжного відділу християн віри євангельської у Львівській об- 
ласті. Вона об’єднує молодь з різноманітних вищих навчальних закладів України. Зібрання відбуваються у закладах вищої освіти, де студенти мають змогу озвучити запитання та висловити міркування щодо різноманітних питань, які стосуються релігії в цілому. Мета асоціації-не лише допомогти молодим людям адаптуватися до нового статусу, місця проживання, оточення, але й сприяти утвердженню та поширенню християнських цінностей серед студентів [28].

Отже, функціонування та розвиток пізньопротестантських спільнот на теренах України було нерозривно поєднане з суспільно-політичними подіями, які розгорталися наприкінці 80 - початку 90-х рр. ХХ ст. Розпад Радянського Союзу та проголошення незалежності України стали поштовхом для волевиявлення та релігійного піднесення серед усіх вікових груп. Саме цей час вирізняється найбільш масовим приєднанням до протестантизму, адже люди намагалися заповнити духовну порожнечу, що утворилася на тлі атеїстичної пропаганди радянської влади. Також, протестантизм уособлював щось нове, щось цілковито інше та відмінне, від того, що пропонували Українська греко-католицька та Православна церкви. Музика, танці та форма проведення богослужінь були своєрідним магнітом, які притягували людей. Якщо у перші роки незалежності України пізньопротестантські спільноти характеризувалися своєю імпульсивною та подекуди хаотичною діяльністю, то у перші десятиліття ХХІ ст. функціонування спільнот вирізняється осмисленістю, організованістю та цілеспрямованістю. У 90-ті рр. XX ст. пізньопротестантські спільноти працювали для блага вузького кола людей, яке складали в основному віруючі Церкви. Тоді як сьогодні функціонування спільнот вийшло на цілковито новий рівень, де важливе місце посідає соціальна та просвітницька діяльність. Насамперед, активність протестантів зосереджується не лише в межах церковної спільноти, але й поза нею. Проте, щонайважливіше, члени протестантських груп особистим прикладом поширюють у молодіжному середовищі християнський спосіб життя.

Незважаючи на прогресивні зміни, впровадження та інновації, сучасний пізньопротестантський рух характеризується замкнутістю та подекуди консервативністю. Якщо молоде покоління протестантів намагається не відставати від тенденцій та викликів XXI ст., то старше покоління виявляє обережність щодо змін та пропозицій. Це свідчить, що протестантські спільноти перебувають на ідейному та ціннісному перехресті, де ще цілковито не відкинуті старі, проте й не прийняті нові бачення та стратегії розвитку, основна ціль яких - утвердження та поширення християнського світогляду серед усього населення. Зазначене ціннісне перехрестя можна вважати спадком політики радянської влади щодо протестантських віруючих, які перебуваючи у підпіллі були вимушені приховувати свою діяльність від ворожого зовнішнього світу. Період виходу за рамки спільноти у пізньопротестантських середовищах тривав значно довше, аніж видавалося спочатку. 


\section{Науковий щорічник “Історія релігій в Україні”. 2019. Вип. 29.}

1. Історія релігії в Україні: у 10 т. / за ред. П. Яроцького. Київ: Світ знань, 2002. Т. 5: Протестантизм в Україні. 424 с.

2. Історія релігії в Україні: у 10 т. / за ред. П. Яроцького. Київ-Дорогобич: Сурма, 2008. Т. 6: Пізній протестантизм в Україні. 632 с.

3. Яроцький П. Л. Різноаспектний характер Європейської Реформації та особливості iii сприйняття в Україні. URL: https:/uars.info/prints/ur/83/12.pdf (дата звернення - 27.07. 2018).

4. Любащенко В. І. Зародження Реформації. Віросповідна сутність протестантизму. Матеріали з сайту Релігійно-інформаційної служби України. URL: https:/risu.org.ua/ua/library/ books/autors/liubaschenko/history_of_protestantism_in_UA/vlub_history_1/65777/ (дата звернення - 25.07. 2018).

5. Любащенко В. І. Історія протестантизму в Україні. Матеріали з сайту Релігійноінформаційної служби України. URL: https://risu.org.ua/ua/library/books/autors/liubaschenko/ history_of_protestantism_in_UA/vlub_history_11/65788/ (дата звернення - 26.07. 2018).

6. Мокієнко М. М. Пізній протестантизм в Україні: інституційний та суспільно-політичний аспекти (1991-2004 рр.): автореф. дис. ... канд. іст. наук: 07.00.01 / Запорізький національний університет. Запоріжжя, 2007. 20 с.

7. Черенков М. М. Соціокультурний вплив ідей реформації на соціально-богословську ідентифікацію українського євангельського протестантизму. URL: http://www.filosof.com.ua/ Jornel/M_67/Cherenkov.pdf (дата звернення - 27.07. 2018).

8. Черенков М. М. Від ізоляціонізму до “входження у світ": соціально-філософські рефлексії трансформаційних процесів в українських євангельських церквах // Мультиверсум: філософський альманах. 2008. № 70. С. 237-242.

9. Черенков М. М. Європейська Реформація та український євангельський протестантизм: монографія. Київ: Християнська просвіта, 2008. 566 с.

10. Буга Є. В. Протестантизм в українському суспільстві: історія виникнення та специфіка функціонування // Релігія та Соціум. 2012. № 2(8). С. 159-164.

11. Буга Є. В. Соціальні доктрини протестантизму в контексті соціокультурних перетворень українського суспільства // Наукові праці [Чорноморського державного університету імені Петра Могили]. Серія: Соціологія. 2013. Т. 225. Вип. 213. С. 35-40.

12. Докаш В. І. Протестантський модернізм: історія, форми вияву в умовах глобалізації та інкультурації українського суспільства // Українське релігієзнавство. 2015. № 73. С. 301-311.

13. Докаш В. І. Форми реалізації особистості в контексті соціальних доктрин протестантських церков // Релігія та соціум. 2010. № 1. С. 104-109.

14. Докаш В. І. Основні складові протестантської есхатології: структурно-функціональний аналіз // Релігія та соціум. 2014. № 3-4. С. 91-98.

15. Шевченко В. М. Словник-довідник з релігієзнавства. Київ: Наукова думка, 2004. 558 с.

15. Религиоведение: словарь / под ред. Е. С. Элбакян. Москва: Академический Проект, 2007. $638 \mathrm{c}$.

16. Религиоведение: энциклоп. слов. / под ред.: А. П. Забияко, А. Н. Красникова, Е. С. Элбакян и др. Москва: Академический проект, 2006. 1255 с.

17. Історія релігії в Україні: у 10 т. / за ред. А. Колодного. Київ: Український видавничий консорціум, 2011. Т. 7: Релігійні меншини України. 600 с.

18. П’ятидесятництво. Довідник релігій. Матеріали з сайту Релігійно-інформаційної служби України. URL: https://risu.org.ua/ua/index/reference/major_religions/ \% $\% 0 \% 9 \mathrm{~F} \% 27 \%$ D1\%8F\%D1\%82\%D0\%B8\%D0\%B4\%D0\%B5\%D1\%81\%D1\%8F\%D1\%82\%D0\%BD \%D0\%B $8 \% \mathrm{D} 1 \% 86 \% \mathrm{D} 1 \% 82 \% \mathrm{D} 0 \% \mathrm{~B} 2 \% \mathrm{D} 0 \% \mathrm{BE} / 33652 /$ (дата звернення - 26.07.2018). 
19. Дані Департаменту у справах релігій та національностей Міністерства культури України. Звіт про мережу церков і релігійних організацій в Україні станом на 01.01.2018 p. URL: https://risu.org.ua/ua/index/resourses/statistics/ukr_2018/70440/ (дата звернення - 25.07. 2018).

20. Рєшетніков Ю., Санніков С. Огляд історії Свангельсько-баптистського братства в Україні. Одеса: Богомисліє, 2000. 230 с.

21. Поширення і розвиток баптистського руху у Східній Галичині у 20-30-х роках XX ст. Матеріали з сайту Львівського музею історії релігії. URL: http://www.museum.lviv.ua/ virtualni-vystavky/516-poshyrennia-i-rozvytok-baptystskoho-rukhu-u-skhidnii-halychyni-u-20-30kh-rokakh-khkh-st (дата звернення - 26.07. 2018).

22. Історія релігії в Україні: навч. посіб. для студентів вищих навчальних закладів / за ред.:

А. М. Колодного, П. Л. Яроцького. Київ: Знання, 1999. 735 с.

23. Інтерв’ю з М. Мокієнком, 1981 р. н., записане у м. Львові 26 лютого 2018 р. // Архів О. Ю. Луців.

24. Інтерв'ю з Я. Назаркевичем, 1971 р. н., записане у м. Львові 7 лютого 2018 р. // Архів О. Ю. Луців.

25. Інтерв’ю з В. Салайдяком, 1975 р. н., записане у м. Львові 9 лютого 2018 р. // Архів О. Ю. Луців.

26. Інтерв’ю з Б. Луцем, 1980 р. н., записане у м. Львові 14 лютого 2018 р. // Архів О. Ю. Луців.

27. Інтерв’ю з І. Біликом, 1983 р. н., записане у м. Львові 1 лютого 2018 р. // Архів О. Ю. Луців.

28. Інтерв’ю з М. Хром'яком, 1988 р. н., записане у м. Львові 13 лютого 2018 р. // Архів О. Ю. Луців.

\section{SUMMARY}

\section{Olena Lutsiv}

\section{Late Protestant Communities in Ukraine (the 19th - the beginning of the 21st century)}

The history of the origin and functioning of the late protestant communities on the territory of Ukraine is investigated. Also, attention is paid to modern trends in the development of late protestant communities, external and internal activities and work with youth. It is revealed that Ukrainian protestantism of the 21 st century is at an ideological and value crossroads, which can be considered as the legacy of Soviet power policy towards protestant believers who, while underground, were forced to conceal any activity from the hostile external world. It is traced that the collapse of the Soviet Union and the proclamation of Ukraine's independence led to a massive accession to protestantism, because people tried to fill the spiritual emptiness that was formed against the background of atheistic propaganda of Soviet power. In addition, protestantism embodied something new and completely different from that offered the UGCC and the Orthodox Church in Ukraine. It is substantiated that in the first years of Ukrainian independence, the late protestant communities were characterized by their impulsive and sometimes chaotic activity, while in the first decades of the 21 st century the activities of communities are intelligent, organized and purposeful. In the 1990s late protestant communities worked for the benefit of a narrow circle of people, which consisted mostly of religious churches. At the same time, today, the functioning of communities has reached a completely new level, where social and educational activities play an important role. First of all, the activity of protestants is concentrated not only within the framework of the church community, but also outside it. However, the most important thing is that members of the community spread a christian way of life among the youth environment by personal example.

Keywords: Protestantism in Ukraine, early Protestantism, late Protestantism, Baptism, Pentecostalism, youth in Protestant churches 